\title{
Expanding the Enterprise Exports by E-business
}

\author{
Hongxin Li \\ School of Economics and Management, Changchun University of Science and Technology \\ Changchun 130022, China \\ E-mail:609677303@qq.com
}

Weihe Duan

School Hospital, Changchun University of Science and Technology, Changchun 130022, China

\begin{abstract}
With unexampled advantages, E-business has developed quickly, and enterprises should have to grasp this opportunity. At present, the problems about expanding the enterprise exports by E-business mainly include that the innovation of international trade enterprise mode in the E-business environment is deficient, the informationization level of enterprise should be further enhanced, the senior E-business talents are deficient, and the support system of E-business should be further perfected. Therefore, to expand the enterprise exports by E-business should innovate the trade mode, establish wide international market sales channel, strengthen the E-business talent cultivation, quicken the information infrastructure construction, and largely push the enterprise informationization.
\end{abstract}

Keywords: International trade mode, Informationization, Enterprise exports, E-business

\section{Development introduction of E-business}

\subsection{Introduction of E-business}

E-business (E-commerce or E-trade) is mode to realize the business by internet. Generally speaking, E-business can be defined as the application of electric tools in businesses, and narrowly speaking, E-business can be defined as that the persons who grasp information technology and business rules in the modern society with highly developed technology and economy utilize electric tools to engage in various activities taking the commodity exchange as the center with high efficiency and low cost.

Comparing with traditional business, the development of E-business is a jump of quality, and essentially, E-business has following characteristics, (1) the trade of E-business is not limited in one country or area; (2) the currency used in E-business is electric currency; (3) the trading personnel in E-business is concealed; (4) the trading locale in E-business is visual; (5) the trading information carrier in E-business is digital and immaterial.

The development tendencies of E-business include depth, individuality, specialization, internationalization, regionalization, and integration.

\subsection{Expanding enterprise exports by E-business}

E-business has many advantages such as spanning time-space, high speed, low cost, individuality, large information, convenience, and high efficiency which could not be compared by traditional business mode, and it quickens the information communication between interior information and exterior information of enterprise, breaks the time-space limitation of trading and trading mode, largely enhances the management quality and running efficiency of enterprise, reduces the operation cost, effectively enhance the market competitive force and influencing force, and provides more and more flexible selections and boons for consumers. In business operation, E-business has many functions such as drumbeating, consultation, internet ordering, internet payment, E-account, service transfer, opinion consultation, and trading management. At the same time, E-business could be also applied in the enterprise management and the rebuilding of interior industrial structure.

According to relative surveys, the scale of E-business market in 2000 was bout 300 billion dollars, and in 2010, the trading amount will achieve 1000 billion Yuan, and the development is very quick. Many enterprises or merchants have early adopted the running mode more depending on the information resource. Network, communication, and information technology gestate infinite opportunities, and the network market breaks the boundaries and territories, and each commercial organization has to adjust his original organization structure and management mode to adopt this change. 
To expand the enterprise export of E-business could enter into various industries of one country and exert increasingly important function. According to relative materials, there are 1.3 billion population in China, and about 0.3 billion urban population, and in fact, the population that may participate in the network economy and E-business in China is close, even more than the population in US, but the network populations' purchasing capacities in two countries are largely different, that determines the occurrence of the pricing problem of commodities purchased in the network.

For E-business, enterprises may failure to do it now, but they will certainly regret that they didn't do it. E-business represents the development direction of future trade, and various enterprises, administration units will all try to realize E-business. Therefore, to expand enterprise exports by E-business is the key direction of the society, which could bring benefits for the country, the society, and the people.

\section{Main problems about expanding enterprise exports by E-business}

\subsection{The innovation of the international trade enterprise mode is deficient}

At present, the E-business in China is in the mode on the level of copy and simulation, and the innovation mode combining with the national situation of China is deficient. The theme of the electric business market in 2007 is the mode innovation, and the Alibaba going public indicates that the service providers in the domain of B2B begun to develop the market, which pricked up the good competition in the domain, widened the capacity of the domain of $\mathrm{C} 2 \mathrm{C}$ where many business tycoons begun to establish the platform of $\mathrm{B} 2 \mathrm{C}$ by traditional channel marketing, which largely promotes the development of the E-business domain, and brings associations with the future market. Since 2003, the E-business Market has gone through four stages including the budding period, the rudiment period, and the quick development period, and the E-business market of China has gone to the period of comprehensive application, but the international trading mode could be developed only by continual innovation.

\subsection{The level of enterprise informationization is lower}

The enterprise informationization is closely correlated with E-business, and it is the base to develop the E-business. As the body of E-business, lagged informationization of enterprise will seriously restrict the development of E-business in China. To realize the informationization, the middle and small enterprise of China still will face many difficulties, but is in the start stage. As viewed from the proportion of the informationization investment, the investment proportion in developed countries could achieve $8 \%-10 \%$, but this proportion is only $0.3 \%$ in China. In addition, in foreign countries, the proportion of middle and small enterprises which adopt the informationization measure could achieve above $60 \%$, but this proportion in China is only about $15 \%$, and different enterprises have different proportions.

\subsection{The senior E-business talents are deficient}

The senior talents of E-business theory, planning, and management with innovational thinking, are very deficient in China, which is one of big difficult in the development of E-business. E-business is an interdisciplinary domain coming down to many subjects such as computer, economy, management, and law. Sometimes, the simple and mechanical scrambled combinations of "emphasizing electrics but ignoring business" or "emphasizing business but ignoring electrics" occurred in practical life, so it is very difficult to cultivate the senior professional talents and composite talents with E-business technology, finance, commerce, and logistics.

\subsection{The social credit degree and the actual development are not balanced}

The imperfect of the social credit system is the sufficient embodiment of immature socialism market economy, and in some places, the trading behaviors lack in necessary self-discipline and strict social regulation. In the network trading, many problems such as how to protect the commercial secret of enterprise, how to confirm the real identity and reliability of both trading parties, how to ensure the security of network payment, how to deal with the disputes in network trading, and how to achieve satisfactory after service, will largely influence the enterprise and consumers' confidence and enthusiasm to E-business in China.

\subsection{The support system of E-business needs to be further perfected}

As viewed from the practical situation of E-business development in China, the network structure is complex, and different industries and networks could not be associated each other, and various resources are hard to be fully shared, and the network application is lagged after the quick development of network technology, and traditional enterprises are hard to adopt the quick development of information technology. At present, the information infrastructure adapting E-business, the logistical system adapting E-business, the financial payment system adapting E-business, and the information security system adapting E-business all have not been 
perfected.

\section{Countermeasures about expanding enterprise exports by E-business}

\subsection{Innovating trade mode}

The diverse trading modes are very important to expand the trade, enhance the incomes, and avoid the uncertain of exterior market. At present, the trading mode of China is still single and lagged, which is the important factor to restrain enterprises to develop the international market. Therefore, enterprises should adopt multiple measures and trading modes to develop the international market, and especially, they should emphasize the application of the new trading mode, i.e. the E-business. In international trading, E-business could break the information obstacle, time obstacle, space obstacle in traditional trading process, reduce the management cost of enterprise, and strengthen the international competitive advantage of enterprise.

\subsection{Establishing wide international market sales channel}

The international market sales channel is the approach and distribution route that export enterprises export the products to the foreign market, and it is very important to promote the development of market, save the human-resource and time in the sales-promotion, disperse risk, and simplify trading. In international trade, it is very important to select and establish a sales channel adapting the commodity for both parties of export and import, especially for the export party. It could help the products to favorably enter into the international market, and be sold out quickly, and acquire better economic benefits, with proper promotion strategies. For foreign trade enterprises, the sales channel means clients. With sales channels, enterprises will have market and users, and the market of products. Based on original sales channel, enterprises should actively develop new sales channel, and establish a extensive and perfect international sales channel.

\subsection{Strengthening the cultivation of senior E-business talents}

In China, the professional talents engaging in the research and application of E-business are deficient. The government of China should increase the investment in the research and application of E-business, standardize various professional trainings and assessments of E-business, strengthen the cultivation of E-business research and application talents, and cultivate the entrepreneurs and managers being familiar with E-business application and technology and laws, and in this way, the running mechanism with good development of E-business could be formed in China.

\subsection{Quickening the information infrastructure construction and largely push the enterprise informationization}

Enterprise is the important body to push E-business, and the active participation of enterprise is the necessary guarantee to develop E-business. Without the base of good benefit and interior drive of pursuing development, enterprises will lack in the informationization consciousness and the enthusiasm to develop E-business.

The application and development of E-business should depend on completed information infrastructure. The gap of the information infrastructure construction between China and foreign countries may make us lose the opportunity that E-business brings to economic development, and increase the gap with developed countries in the competition. To promote the development of E-business in China, enterprises should effectively utilize existing network resource when quickening the construction of information infrastructure.

Therefore, to develop the E-business with Chinese characteristics, Chinese government should establish the E-business development frame according with the national situation of China, plan the whole strategy and the implementation measure of E-business, establish the information exchange technical standard and criterion according with international criterions, independently research and develop relative technologies and products of E-business, constitute and perfect relative laws and regulations, provide a good industrial environment for the spanning development of E-business in China, and push the industrialized development of E-business in China more comprehensively, actively, and quickly.

\section{References}

Chen, Jin. (2006). E-business Finance and Safety. Beijing: Tsinghua University Press.

Song, Ling \& Wang, Xiaoyan. (2006). E-business Strategy. Beijing: China Financial Publishing House.

Wu, Guohua. (2003). Tendency of the Foreign Trade Development of China of 2003. Foreign Trade Economics \& International Trade. No.5.

Yang, Jianzheng. (2004). Analysis of E-business Cases. Beijing: Chinese People University Press.

Zhang, Runtong. (2003). Introduction of E-business. Beijing: Electronic Industry Press. 